\title{
Spatial and temporal effects of fish farming on benthic community structure in a semi-enclosed gulf of the Eastern Mediterranean
}

\author{
Nikos Neofitou*, Dimitris Vafidis, Spyros Klaoudatos \\ Department of Ichthyology and Aquatic Environment, School of Agriculture, University of Thessaly, Fytokou str., N. Ionia, \\ 38446 Volos, Greece
}

\begin{abstract}
Spatial and temporal effects of fish farming on the benthic community structure at 2 fish farms in the Eastern Mediterranean were investigated between July 2004 and April 2005. In the area of each fish farm, 3 stations were sampled. At each station, sediment samples were collected for analysis of organic carbon, organic matter and benthic community parameters. There were statistically significant differences in organic matter and organic carbon among all stations. This impact seems to be only spatial, since 1-way ANOVA indicated no significant differences in organic matter and organic carbon between seasons for both farms. Furthermore, significant differences were found in species number, abundance and species richness among stations and seasons for one of the farms (2-way ANOVA). One-way ANOVA indicated that the significant differences, detected in the benthic community parameters of this farm, were spatio-temporal for species number, temporal for abundance and spatial for species richness. The spatial effect of fish farming on benthic community structure was present up to $50 \mathrm{~m}$ from the centre of cages on one farm and between 50 and $300 \mathrm{~m}$ from the other farm. Capitella capitata was the most dominant species at the farm sites, while Nephthys hystricis was the most dominant species at the control sites. In all cases, the benthic assemblages in the immediate vicinity showed symptoms of disturbance, but the spatial and temporal extent of this effect was less than one would expect considering the fact that the study area is located in a semi-enclosed gulf.
\end{abstract}

KEY WORDS: Aquaculture $\cdot$ Environmental impact $\cdot$ Macrobenthos $\cdot$ Mediterranean

\section{INTRODUCTION}

During the last $25 \mathrm{yr}$, aquaculture has proliferated in the coastal zone, becoming an increasingly important industry. The use of net pens for aquaculture has grown rapidly since 1990, primarily as a result of the widespread interest in growing salmonids and other marine fish (Tucker \& Hargreaves 2008). Fish farming was once considered an environmentally benign practice, but is now viewed as a potential polluter of the marine environment (Findlay et al. 1995). Organic enrichment of the seabed is the most widely encountered effect of culturing fish in cages (Karakassis et al. 2000, Karakassis et al. 2002). Increasing organic load in sediments might have a strong effect on the structure of benthic communities (Karakassis et al. 2000,
Hyland et al. 2005, Klaoudatos et al. 2006, Yucel-Gier et al. 2007). Deposition of organic material under the cages may cause changes in the composition of basic benthic communities in terms of abundance, dominance and species richness (Pearson \& Rosenberg 1978, Wu et al. 1994). The effects described here tend to be localized around effluent discharge points and within $25 \mathrm{~m}$ of the perimeter of net-pen farms (Karakassis et al. 2000, Pearson \& Black 2001). Particularly in semi-enclosed marine areas with weak currents, the sediment characteristics beneath and around fish farm cages change with the accumulation of uneaten food, metabolic waste and faeces (Maldonado et al. 2005).

Previous studies in the Mediterranean have addressed the effects of fish farming on water column chemistry and parasites (Papoutsoglou et al. 1996), on 
seagrass (Delgado et al. 1999), on nutrients and plankton (Pitta et al. 1999, Yucel-Gier et al. 2007, Neofitou \& Klaoudatos 2008, Yucel-Gier et al. 2008, Basaran et al. 2010), on benthic community structure (Katavic \& Antolic 1999, Karakassis et al. 2000, Mazzola et al. 2000, La Rosa et al. 2001, Mirto et al. 2002, Belias et al. 2003, Klaoudatos et al. 2006, Yucel-Gier et al. 2007), on the dynamics of sediment accumulation beneath cages (Karakassis et al. 1998), on the biological and geochemical properties of muddy and sandy sediments (Papageorgiou et al. 2010), on the recovery process of benthos after cessation (Karakassis et al. 1999) and on changes to wild fish assemblages (Dempster et al. 2002, Machias et al. 2004, Machias et al. 2005). Most of the aforementioned studies have addressed the environmental impact of fish farming without investigating its spatial and temporal extent. Karakassis et al. (2000) have indicated that the effects of aquaculture on the benthic environment are found within a short distance, normally not exceeding 25 to $30 \mathrm{~m}$ from the edge of fish cages; however, it is well known that fish farming releases a substantial amount of nutrients into the marine environment (Holby \& Hall 1991, Hall et al. 1992) and it would, therefore, be reasonable to expect effects at larger spatial scales, particularly when a zone of farms is established in a coastal gulf. Such large scale effects have been reported by Pohle et al. (2001) from the Canadian coast, showing signs of stress for benthic macrofauna at distances $>200 \mathrm{~m}$ from any fish farm in that area.

Farming of sea bream and sea bass in the Mediterranean has traditionally been dominated by Egypt,
Greece, and Turkey (Maldonado et al. 2005). Similar to Atlantic and Pacific salmon farms, most of these Eastern Mediterranean sea bass and sea bream farms are located at shallow sheltered sites and in semi-enclosed gulfs, representing favoured location choices in view of the complex coastal structure of Greece, Croatia, and Turkey (Basurco 2000). The situation is quite different for most fish farms that have been installed in some Western Mediterranean countries in the last decade. About $50 \%$ of the 45 production units operating in Spain in 1998 had cages in semi-exposed and exposed conditions (Basurco \& Larrazabal 2000). From an ecological point of view, it is assumed that limited water exchange in semi-enclosed gulfs may result in a more apparent environmental impact than is found in farms under semi-exposed conditions.

The objective of this study was to assess the spatial and temporal variability of the effect of aquaculture facilities on macrobenthos structure in a semi-enclosed gulf of the Eastern Mediterranean.

\section{MATERIALS AND METHODS}

Study area. Pagasitikos is located in the Western Aegean Sea (Eastern Mediterranean; Fig. 1). The mean depth is $69 \mathrm{~m}$. The deepest area $(108 \mathrm{~m})$ is found at the eastern part of the gulf. The total area is $520 \mathrm{~km}^{2}$ connected with the Aegean Sea and North Evoikos through the narrow $(5.5 \mathrm{~km})$ and relatively deep $(80 \mathrm{~m})$ Trikeri Channel. The mean water renewal time of Pagasitikos is $105 \mathrm{~d}$ (Petihakis et al. 2002).

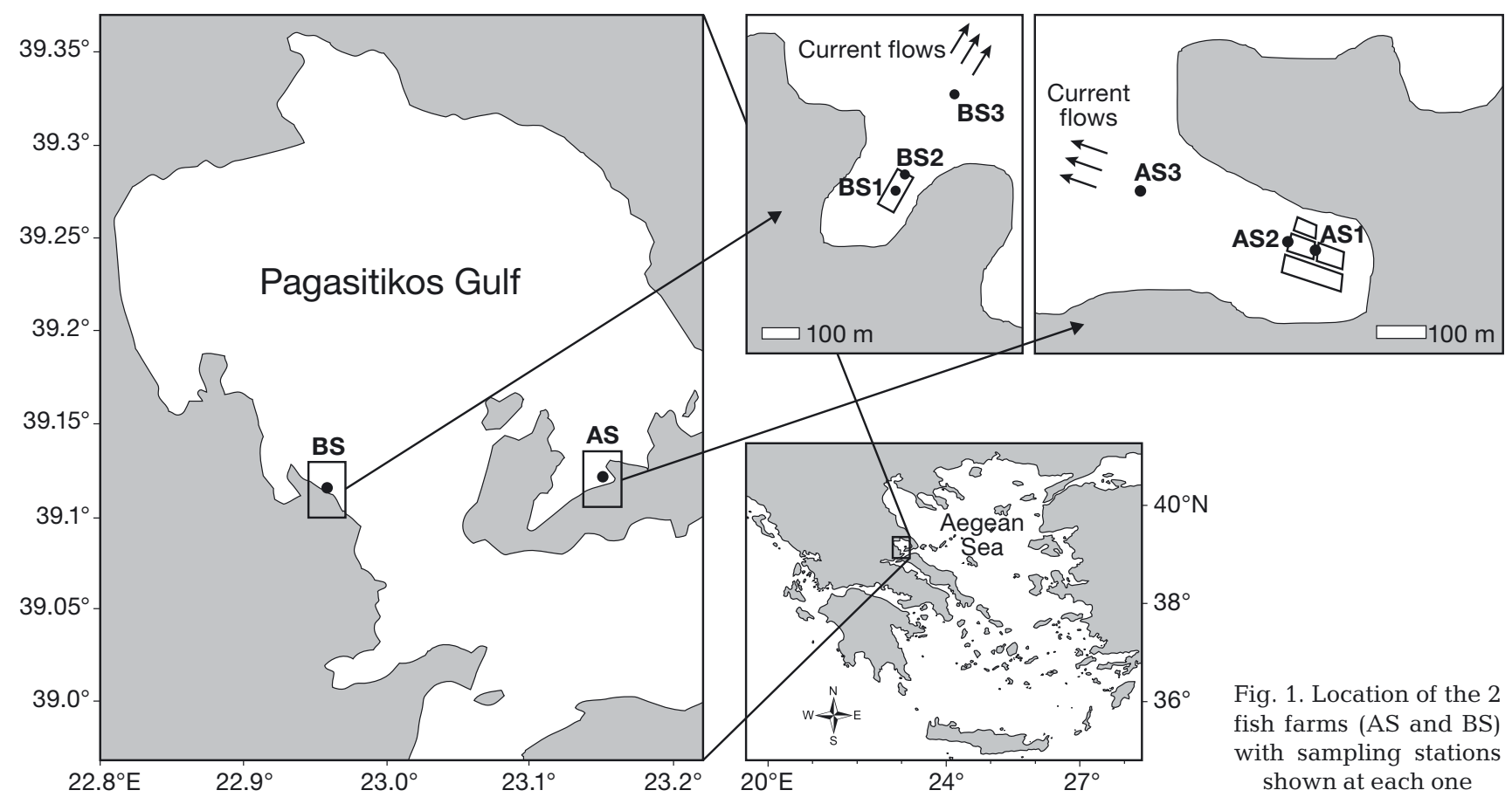


Two marine fish farms were examined: The first (31 to $36 \mathrm{~m}$ depth) is situated at the southeast part of Pagasitikos $\left(39^{\circ} 07^{\prime} 38^{\prime \prime} \mathrm{N}, 23^{\circ} 09^{\prime} 17^{\prime \prime} \mathrm{E}\right)$; the second (28 to $38 \mathrm{~m}$ depth) is situated at the southwest part of Pagasitikos (3907' 13" N, 22 $\left.2^{\circ} 57^{\prime} 53^{\prime \prime} \mathrm{E}\right)$. These are henceforth referred to as AS and BS farms, respectively (Fig. 1). Sea bream Sparus aurata and sea bass Dicentrarchus labrax are intensively cultured in these farms where they are fed both pelleted and extruded diets. At the time of the study, the average annual standing stocks were 130 and $92 \mathrm{t}$, and the food conversion ratios (FCR) were 1.7 and 2.0 for AS and BS farms, respectively. The AS farm had 18 polyethylene cages: 12 cages $(7.5 \times 15 \times 8 \mathrm{~m}$, length $\times$ width $\times$ depth) and 6 cages $(15 \times 15 \times 10 \mathrm{~m})$. The BS farm had 80 polyethylene cages: 8 small cubical cages $(5 \times 5 \times 5 \mathrm{~m})$, 8 slightly larger cubical cages $(7.5 \times$ $7.5 \times 7.5 \mathrm{~m})$ and 64 cuboid cages $(6 \times 6 \times 5 \mathrm{~m})$. The sizes depend on the size of the cultivated fish. The average value of current speed was 3.5 and $4.0 \mathrm{~cm} \mathrm{~s}^{-1}$ for the AS and BS farms, respectively (in 1998 to 1999). For both fish farms, the main current direction was from the land to the centre of Pagasitikos Gulf (Petihakis et al. 2005).

Sampling strategy. Four seasonal samplings were carried out from July 2004 to April 2005 (July and October 2004, January and April 2005) at both fish farms. At each fish farm, 3 stations were sampled, upstream from the main current direction. One was located at the centre of each fish farm (AS1 and BS1), another at a distance of $50 \mathrm{~m}$ from the centre (AS2 and BS2) and the last one at a distance of $300 \mathrm{~m}$ (AS3 and BS3). Stns AS3 and BS3 were used as controls and were located in the same direction as Stns AS2 and BS2 in relation to Stns AS1 and BS1, respectively (Fig. 1). The greater depth and distance from farms of control stations compared to other stations placed the controls at minimal stress from fish farming and as close as possible to the natural environmental conditions at the farms.

Grain-size analysis was performed at all stations using standard sieving and settling procedures (Buchanan 1971). Sediment type classification was based on the relative percentages of clay $(<0.002 \mathrm{~mm})$, silt (0.002 to $0.063 \mathrm{~mm}$ ) and sand (0.063 to $2 \mathrm{~mm}$ ) (Wentworth 1922).

Sediment samples for organic matter, organic carbon and benthic community analysis, were collected by means of an Eckman-Birge Grab sampler $\left(225 \mathrm{~cm}^{2}\right)$. From all the sampling stations, 3 replicate samples were taken during all seasons.

For the analysis of organic matter and organic carbon, samples were stored frozen at $-20^{\circ} \mathrm{C}$. For the analysis of organic matter, we used 2 to $5 \mathrm{~g}$ (dry weight) sediment sub-samples. After homogenization and drying at $60^{\circ} \mathrm{C}$ to constant weight, sediment was combusted in a furnace (Nabertherm L9) at $500^{\circ} \mathrm{C}$ for $4 \mathrm{~h}$. The amount of organic matter in a sample was esti- mated as the difference between dry and ash weight (Byers et al. 1978). Total organic carbon measurements were carried out according to the inexpensive titration method described by Gaudette et al. (1974) using potassium dichromate and sulphuric acid as the oxidant.

For benthic community analysis, samples were sieved through a $0.5 \mathrm{~mm}$ mesh sieve and each sample was placed in a plastic vial in $10 \%$ formaldehyde. Samples were sorted by hand into major taxa (Polychaeta, Mollusca, Crustacea, Echinodermata and Sipunculida) and a 'miscellaneous' category, and specimens were identified to species level under a stereomicroscope (Olympus SZX9). The number of individuals (ind. $\mathrm{m}^{-2}$ ) was determined separately for each species, while dry biomass $\left(\mathrm{g} \mathrm{m}^{-2}\right)$ was determined in total for all species.

Data analysis. Community parameters were calculated for each station in each sampling period. Diversity was calculated by means of the $\left(\log _{2}\right)$ ShannonWiener index $\left(H^{\prime}\right)$ (Shannon \& Weaver 1949), species richness $(d)$ was calculated after Margalef (1958) and species evenness $\left(J^{\prime}\right)$ after Pielou (1977). Cluster analysis was performed using the Bray-Curtis similarity index (Bray \& Curtis 1957) to obtain the degree of similarity in species composition between sampling stations of the 2 areas studied. Furthermore, Multidimensional Scaling (MDS) ordination analysis (Field et al. 1982) was performed using the Bray-Curtis similarity index (Bray \& Curtis 1957) to obtain a 2D plot of the spatial and temporal changes in species composition of macrofaunal assemblages at each of the 2 areas studied. Before this, a 4 th root transformation of the data reduced the influence of dominant and rare species (Clarke \& Gorley 2006). K-dominance curves, with cumulative ranked abundance plotted against species rank, in decreasing order of their importance, were used as a graphical representation of the effects relating to levels of biological stress (Clarke \& Warwick 1994). The SIMPER analysis was used to investigate the contribution of each species to the average BrayCurtis dissimilarity between samples from the farm (AS1, AS2, BS1 and BS2) and the control (AS3 and BS3) stations of the AS and BS farms (Clarke \& Gorley 2006). Calculations were done using the PRIMER software package. Data for statistical analysis were evaluated for normal distribution by employing the Aderson-Darling test for normality and homogeneity of variance by assessing residual plots and employing Bartlett's and Levene's tests when necessary data transformation was performed. One-way analysis of variance (ANOVA) was used to analyze the spatial apart from the temporal effect (response vs. station and response vs. season) in sediment and community parameters of the AS and BS farms, while 2-way ANOVA was used to analyze the spatial and temporal effect (response vs. station $\times$ season) simultaneously. 


\section{RESULTS}

\section{Sediment geochemistry}

The sediment at the farm stations was mainly composed of sand (62.3 to $79.4 \%$ ), while that at the control stations was mostly sandy mud (Table 1). These differences did not influence the community composition.

The maximum concentration of organic matter was $7.73 \%$ at the AS farm and $18.30 \%$ at the BS farm (Table 2). Furthermore, the maximum concentrations of organic carbon were 1.58 and $4.21 \%$ for the AS and BS farms, respectively (Table 2). Organic matter concentrations were approximately a factor of 2.5 and 1.5 higher at the farm stations compared to the control stations at the AS and BS farms, respectively (Table 2,

Table 1. Average particle-size distribution (\%) at the sampling stations of the AS and BS farms (3 replicates per sampling station, 1 sampling period)

\begin{tabular}{lcccccc|}
\hline & AS1 & AS2 & AS3 & BS1 & BS2 & BS3 \\
\hline Sand & 79.4 & 73.5 & 48.9 & 74.0 & 62.2 & 59.9 \\
Silt & 8.6 & 12.0 & 38.8 & 13.5 & 26.8 & 30.9 \\
Clay & 12.0 & 14.5 & 12.3 & 12.5 & 11.0 & 9.2 \\
\hline
\end{tabular}

Fig. 2). Furthermore, organic carbon concentrations were approximately a factor of 4 and 2 higher at the farm stations compared to the control stations at the AS and BS farms, respectively (Table 2, Fig. 2). The maximum values of organic matter and organic carbon were measured in spring at Stns AS1 and BS1, while the minimum values were measured in winter (Table 2). The results of statistical comparisons between concentrations of organic matter and organic carbon for all sampling stations and seasons at the AS and BS farms indicated significant differences (2-way ANOVA). This impact seems to be only spatial, since 1-way ANOVA indicated no significant differences between seasons for both farms (Table 3).

\section{Macrofauna}

A total number of 3536 individuals, belonging to 90 species were identified. The minimum number of species was encountered at the AS1 and BS1 sampling stations (22 and 18, respectively; Table 2). The maximum macrofaunal abundance was recorded in summer (2978 ind. $\mathrm{m}^{-2}$ ) at the AS farm (AS3) and in spring (3941 ind. $\mathrm{m}^{-2}$ ) at the BS farm (BS1; Table 2, Fig. 2). This was also the case for the values of dry biomass (8.07 and $13.07 \mathrm{~g} \mathrm{~m}^{-2}$ at the AS and BS farms, respec-

Table 2. Minimum, maximum and mean $\pm \mathrm{SE}$ of sediment and benthic community parameters at the sampling stations of the AS and BS farms over all sampling cruises (four seasons)

\begin{tabular}{|c|c|c|c|c|c|c|}
\hline Parameter & AS1 & AS2 & AS3 & BS1 & BS2 & BS3 \\
\hline \multicolumn{7}{|l|}{ OM (\%) } \\
\hline Range & $6.59-7.73$ & $4.39-5.93$ & $2.03-2.97$ & $15.87-18.30$ & $12.97-14.13$ & $8.85-11.73$ \\
\hline Mean $\pm \mathrm{SE}$ & $7.16 \pm 0.23$ & $5.34 \pm 0.35$ & $2.58 \pm 0.20$ & $16.75 \pm 0.53$ & $13.40 \pm 0.26$ & $10.10 \pm 0.66$ \\
\hline \multicolumn{7}{|l|}{$\mathrm{OC}(\%)$} \\
\hline Range & $1.35-1.58$ & $0.57-0.84$ & $0.21-0.32$ & $3.28-4.21$ & $2.75-3.18$ & $1.52-1.71$ \\
\hline Mean $\pm \mathrm{SE}$ & $1.47 \pm 0.05$ & $0.74 \pm 0.06$ & $0.27 \pm 0.02$ & $3.78 \pm 0.22$ & $2.97 \pm 0.10$ & $1.63 \pm 0.04$ \\
\hline \multicolumn{7}{|c|}{ Number of species } \\
\hline Range & $22-38$ & $35-53$ & $37-49$ & $18-31$ & $32-50$ & $37-49$ \\
\hline Mean $\pm \mathrm{SE}$ & $30 \pm 3.33$ & $42 \pm 3.87$ & $43 \pm 2.58$ & $25 \pm 2.86$ & $40 \pm 3.71$ & $43 \pm 2.50$ \\
\hline \multicolumn{7}{|c|}{ Abundance (ind. $\mathrm{m}^{-2}$ ) } \\
\hline Range & $1348-2222$ & $1289-2281$ & $1748-2978$ & $1600-3941$ & $1763-3363$ & 1852-2933 \\
\hline Mean $\pm \mathrm{SE}$ & $1644 \pm 196.25$ & $1778 \pm 223.15$ & $2122 \pm 289.24$ & $2881 \pm 517.34$ & $2444 \pm 341.51$ & $2381 \pm 251.76$ \\
\hline \multicolumn{7}{|c|}{ Dry biomass $\left(\mathrm{g} \mathrm{m}^{-2}\right)$} \\
\hline Range & $6.12-7.21$ & $5.46-7.52$ & $6.59-8.07$ & $6.92-13.07$ & $7.32-11.85$ & $7.00-9.25$ \\
\hline Mean \pm SE & $6.57 \pm 0.23$ & $6.74 \pm 0.45$ & $7.26 \pm 0.31$ & $10.23 \pm 1.53$ & $8.78 \pm 1.05$ & $8.05 \pm 0.56$ \\
\hline \multicolumn{7}{|c|}{ Shannon-Wiener $\left(H^{\prime}\right)$} \\
\hline Range & $2.43-2.74$ & $3.28-3.61$ & $3.32-3.59$ & $1.56-1.90$ & $2.72-3.07$ & $3.30-3.48$ \\
\hline Mean $\pm \mathrm{SE}$ & $2.64 \pm 0.07$ & $3.39 \pm 0.08$ & $3.42 \pm 0.06$ & $1.70 \pm 0.08$ & $2.88 \pm 0.08$ & $3.41 \pm 0.04$ \\
\hline \multicolumn{7}{|c|}{ Species richness $(d)$} \\
\hline Range & $4.80-15.78$ & $4.75-6.72$ & $4.80-6.00$ & $2.17-3.68$ & $4.04-6.03$ & $4.78-6.01$ \\
\hline Mean \pm SE & $3.94 \pm 0.40$ & $5.48 \pm 0.44$ & $5.49 \pm 0.28$ & $3.02 \pm 0.32$ & $5.07 \pm 0.41$ & $5.47 \pm 0.25$ \\
\hline \multicolumn{7}{|c|}{ Species evenness $\left(J^{\prime}\right)$} \\
\hline Range & $0.74-0.81$ & $0.90-0.93$ & $0.89-0.93$ & $0.45-0.61$ & $0.75-0.84$ & $0.88-0.91$ \\
\hline Mean $\pm \mathrm{SE}$ & $0.78 \pm 0.01$ & $0.91 \pm 0.01$ & $0.91 \pm 0.01$ & $0.53 \pm 0.03$ & $0.78 \pm 0.02$ & $0.90 \pm 0.01$ \\
\hline
\end{tabular}



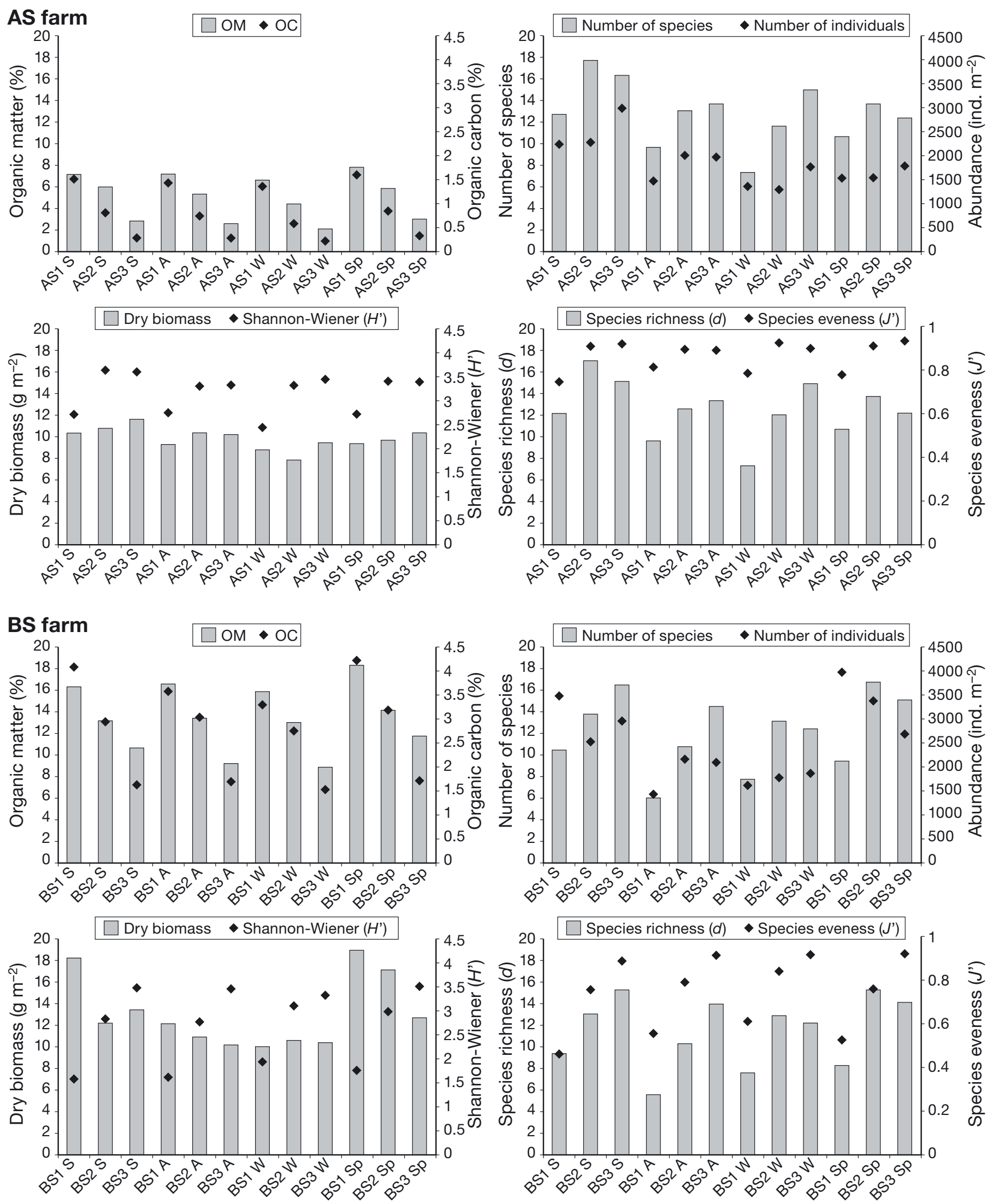

Fig. 2. Mean of sediment and benthic community parameters at the sampling stations of the AS and BS farms for all seasons. S: summer; A: autumn; W: winter; Sp: spring 
Table 3. Results of statistical comparisons between sediment and benthic community parameters for all sampling stations at the AS and BS farms. OC: organic carbon; OM: organic matter; S: number of species; N: number of individuals; $H^{\prime}$ : Shannon-Wiener index; $d$ : species richness; $J^{\prime}$ : species evenness. ${ }^{*} \mathrm{p}<0.05,{ }^{* *} \mathrm{p}<0.001, \mathrm{~ns}$ : not significant

\begin{tabular}{|c|c|c|c|c|c|c|c|c|}
\hline \multirow{3}{*}{$\begin{array}{l}\text { Farm } \\
\mathrm{AS}\end{array}$} & \multirow{3}{*}{$\begin{array}{c}\text { Variable } \\
\text { OC }\end{array}$} & \multirow{3}{*}{$\begin{array}{l}\text { df } \\
35\end{array}$} & \multicolumn{2}{|c|}{ Station } & \multicolumn{2}{|c|}{ Season } & \multicolumn{2}{|c|}{ Station $\times$ Season } \\
\hline & & & \multicolumn{2}{|c|}{$F \quad$ p-level } & \multicolumn{2}{|c|}{$F \quad$ p-level } & \multicolumn{2}{|c|}{$F \quad \mathrm{p}$-level } \\
\hline & & & 164.42 & $* *$ & 0.06 & ns & 810.68 & $* *$ \\
\hline & OM & 35 & 73.79 & ** & 0.14 & ns & 389.75 & ** \\
\hline & $\mathrm{S}$ & 35 & 14.94 & ** & 7.79 & ** & 1.40 & $\mathrm{~ns}$ \\
\hline & $\mathrm{N}$ & 35 & 3.31 & * & 18.83 & *** & 2.29 & $\mathrm{~ns}$ \\
\hline & $H^{\prime}$ & 35 & 76.01 & ** & 1.04 & ns & 1.31 & ns \\
\hline & $d$ & 35 & 17.95 & ** & 6.32 & ** & 1.01 & $\mathrm{~ns}$ \\
\hline & $J^{\prime}$ & 35 & 82.39 & ** & 0.37 & ns & 1.87 & ns \\
\hline \multirow[t]{7}{*}{ BS } & $\mathrm{OC}$ & 35 & 61.81 & ** & 0.12 & ns & 110.13 & ** \\
\hline & OM & 35 & 42.20 & ** & 0.23 & $\mathrm{~ns}$ & 156.22 & *** \\
\hline & $\mathrm{S}$ & 35 & 29.04 & ** & 3.81 & * & 2.74 & * \\
\hline & $\mathrm{N}$ & 35 & 1.63 & ns & 23.85 & *** & 5.37 & ** \\
\hline & $H^{\prime}$ & 35 & 344.87 & ** & 0.10 & ns & 1.77 & $\mathrm{~ns}$ \\
\hline & $d$ & 35 & 43.60 & ** & 2.51 & ns & 2.56 & ${ }^{*}$ \\
\hline & $J^{\prime}$ & 35 & 149.23 & ** & 0.51 & $\mathrm{~ns}$ & 1.89 & $\mathrm{~ns}$ \\
\hline
\end{tabular}

tively; Table 2, Fig. 2). The Shannon-Wiener diversity index, species richness and evenness increased with distance from the cages at both farms (Table 2, Fig. 2).

In terms of community structure (Table 4 ), the 2 farms showed a pattern of spatial change with distance from the cages. The polychaete Capitella capitata was the most dominant species at both farms (37 and 65\% of the total abundance at the AS1 and BS1 stations,

Table 4. Average relative abundance (\%) per station of macrofaunal species comprising more than $1 \%$ of the total abundance at any one station over all sampling cruises. +: presence $<1 \%$; C: Crustacea; E: Echinodermata; M: Mollusca; P: Polychaeta; S: Sipunculida. Species are arranged by decreasing average abundance at the stations in proximity to the cages and increasing average abundance at the control stations (AS3 and BS3)

\begin{tabular}{|lccccccc|}
\hline Species & Taxon & AS1 & AS2 & AS3 & BS1 & BS2 & BS3 \\
\hline Capitella capitata & $\mathrm{P}$ & 37 & 13 & + & 65 & 33 & 2 \\
Tharyx dorsobranchialis & $\mathrm{P}$ & 5 & 7 & 6 & 4 & 7 & 5 \\
Harpinia dellavallei & $\mathrm{C}$ & 6 & 5 & 5 & 2 & 5 & 5 \\
Paraonis gracilis gracilis & $\mathrm{P}$ & 3 & 7 & 8 & 3 & 5 & 8 \\
Lumbrinereis gracilis & $\mathrm{P}$ & 3 & 3 & 2 & 2 & 3 & 3 \\
Ampelisca diadema & $\mathrm{C}$ & 2 & 4 & 4 & 3 & 5 & 5 \\
Podarke pallida & $\mathrm{P}$ & 3 & 3 & 3 & 2 & 1 & 3 \\
Glycera convoluta & $\mathrm{P}$ & 3 & 3 & 5 & 1 & 2 & 5 \\
Chaetozone setosa & $\mathrm{P}$ & 2 & 4 & + & 2 & + & 1 \\
Apseudes latreilli & $\mathrm{C}$ & 3 & 3 & 1 & + & 2 & 2 \\
Onchnesoma steenstrupi & $\mathrm{S}$ & 3 & 3 & 4 & + & 2 & 3 \\
Turitella triplicata & $\mathrm{M}$ & 2 & 1 & + & + & 1 & 2 \\
Aricidea fragilis mediterranea & $\mathrm{P}$ & 1 & 1 & 2 & 1 & 1 & + \\
Owenia fusiformis & $\mathrm{P}$ & 2 & 1 & 1 & + & 2 & 2 \\
Mytilus galloprovincialis & $\mathrm{M}$ & & & & 2 & 4 & 1 \\
Corbula gibba & $\mathrm{M}$ & 1 & 1 & 4 & + & + & 4 \\
Amphiura filiformis & $\mathrm{E}$ & 1 & 1 & 3 & + & + & 2 \\
Prionospio ehlersi & $\mathrm{P}$ & 1 & 2 & 2 & + & + & 1 \\
Dentalium sp. & $\mathrm{M}$ & + & 2 & 3 & + & 1 & 3 \\
Notomastus latericeus & $\mathrm{P}$ & + & 2 & 2 & + & 1 & + \\
Nephthys hystricis & $\mathrm{P}$ & & 2 & 11 & & 2 & 11 \\
Total & & 80 & 67 & 68 & 92 & 81 & 72 \\
\hline
\end{tabular}

respectively), whilst the most dominant species at the control stations was the polychaete Nephthys hystricis (11\% of the total abundance at both AS3 and BS3). Furthermore, N. hystricis was found at the control stations and at the AS2 and BS2 stations, but never at the AS1 and BS1 stations which were located under the centre of the cages.

At both farms, the polychaete Capitella capitata was the principal contributor (Table 5) to the observed dissimilarities between samples from the farm and the control stations (the species occurring mainly at the farm stations), followed by the polychaetes Nephthys hystricis and Paraonis gracilis gracilis, both occurring mainly at the control stations. The average dissimilarities between samples from the farm and the control sites were 55.17 and $61.22 \%$ at the AS and BS farms, respectively.

Cluster analysis (Fig. 3) based on the Bray-Curtis similarity index indicated the presence of 3 major groups (Groups A, B, C at the AS farm and D, E, F at the BS farm) at each farm with 56 and $57 \%$ similarity at the AS and BS farms, respectively. Each group consists of a single sampling station except for Group D which includes Stn BS1 during 3 seasons, while Stn BS1 goes to Group E during winter.

MDS results indicate that spatiotemporal patterns in the changes of macrofaunal species composition were similar at both farms (Fig. 4). Each station formed a separate cluster for all sampling seasons at the AS and BS farms. The only exception to this was Stn BS1 which clustered with Stn BS2 during winter.

The K-dominance curve of Stn AS1 shows higher elevation compared to the K-dominance curves of Stns AS2 and AS3, which overlap. K-dominance curves of the BS farm are separated into 3 distinct curves with an increased elevation at Stn BS1 followed by Stns BS2 and BS3 indicating a reduction in diversity (Fig. 5).

The 2-way ANOVA showed no significant differences for all benthic community parameters, except for species number, abundance and species richness at the BS farm (Table 3). Furthermore, 1-way ANOVA indicated that 
Table 5. Top 10 ranked species responsible for the observed dissimilarities between samples from farm (AS1, AS2, BS1 and BS2) and control (AS3 and BS3) stations over all sampling cruises (AS and BS farms) and their average abundances $\left(\mathrm{m}^{-2}\right)$ and individual contribution (\%) to the average dissimilarity value

\begin{tabular}{|c|c|c|c|c|}
\hline \multirow{2}{*}{$\begin{array}{l}\text { Farm } \\
\text { AS }\end{array}$} & Species & \multicolumn{2}{|c|}{$\begin{array}{l}\text { Average abundance } \\
\qquad\left(\mathrm{m}^{-2}\right)\end{array}$} & \multirow{2}{*}{$\begin{array}{c}\begin{array}{c}\text { Average } \\
\text { dissimilarity }(\%)\end{array} \\
55.17\end{array}$} \\
\hline & & $\mathrm{AS} 1 \& \mathrm{AS} 2$ & AS3 & \\
\hline & Capitella capitata & 422 & 7 & 10.9 \\
\hline & Nephthys hystricis & 15 & 230 & 5.6 \\
\hline & Paraonis gracilis gracilis & 85 & 159 & 2,0 \\
\hline & Corbula gibba & 20 & 85 & 1.7 \\
\hline & Dentalium sp. & 20 & 74 & 1.5 \\
\hline & Onchnesoma steenstrupi & 46 & 93 & 1.3 \\
\hline & Ampelisca diadema & 54 & 93 & 1.2 \\
\hline & Podarke pallida & 44 & 74 & 1.1 \\
\hline & Prionospio ehlersi & 28 & 52 & 1.0 \\
\hline & Glycera convoluta & 54 & 96 & 1.0 \\
\hline \multirow[t]{11}{*}{ BS } & & $\mathrm{BS} 1 \& \mathrm{BS} 2$ & BS3 & 61.22 \\
\hline & Capitella capitata & 1339 & 37 & 24.8 \\
\hline & Nephthys hystricis & 20 & 263 & 4.9 \\
\hline & Paraonis gracilis gracilis & 102 & 196 & 1.9 \\
\hline & Corbula gibba & 17 & 96 & 1.7 \\
\hline & Glycera convoluta & 50 & 122 & 1.5 \\
\hline & Tharyx dorsobranchialis & 137 & 126 & 1.3 \\
\hline & Ampelisca diadema & 102 & 130 & 1.0 \\
\hline & Mytilus galloprovincialis & 76 & 26 & 1.0 \\
\hline & Lysianassa longicornis & 30 & 41 & 0.9 \\
\hline & Dentalium sp. & 20 & 67 & 0.9 \\
\hline
\end{tabular}
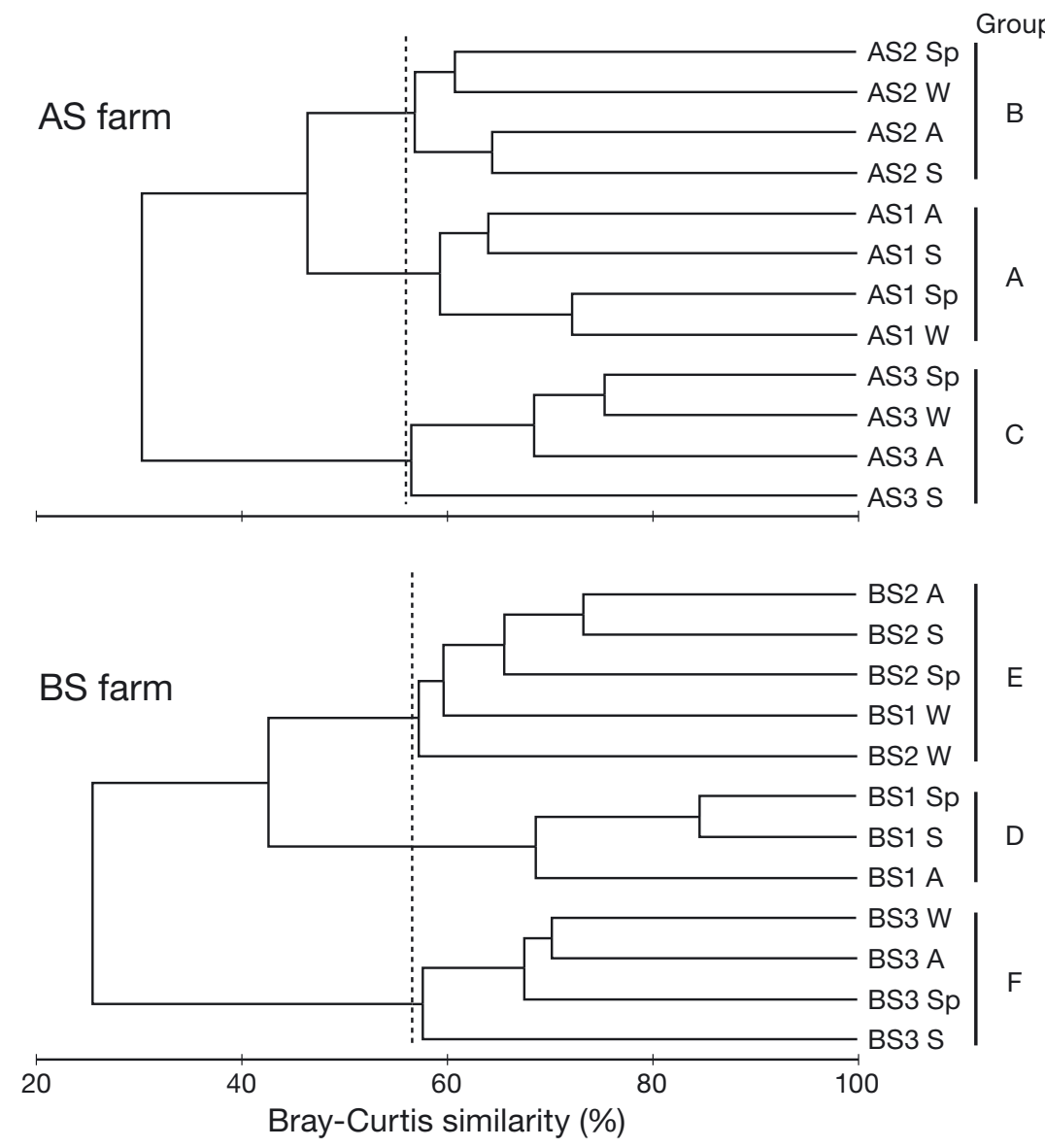

the significant differences, detected in the benthic community parameters of the BS farm, were spatio-temporal for species number, temporal for abundance and spatial for species richness (Table 3).

\section{DISCUSSION}

Increases in sediment concentration of organic matter and organic carbon similar to those found at the farm stations in the present study have been reported for sandy seabed by Weston (1990), Karakassis et al. (2000) and Yucel-Gier et al. (2007). Furthermore, our maximum concentrations of organic matter $(18.30 \%)$ and organic carbon $(4.21 \%)$, which were recorded under the cages of the BS farm, are similar to those previously reported by Karakassis et al. (2000) in Cephalonia Bay (Greece, Eastern Mediterranean). In contrast, accumulation rates of organic matter reported in the literature from other regions of the Western Mediterranean (Spain) are exceptionally low and range from 0.5 to $2.4 \%$, but they refer to fish farms in semi-exposed sites which are assumed to facilitate dissipation of the effects of the suspended solids (Ruiz et al. 2001, Maldonado et al. 2005). Studies in other areas have reported that the accumulation of organic matter can extend from 145 to $205 \mathrm{~m}$ down-current from the perimeter of net pen facilities (Brooks \& Mahnken 2003a), although other scientists conclude that significant effects are usually restricted to less than $60 \mathrm{~m}$ from the perimeter (Nash et al. 2005). Of all the potential environmental impacts of salmonid net-pen aquaculture, changes to the sediment beneath net pens are considered to represent the greatest risk to

Fig. 3. Dendrogram for hierarchical clustering of the macrobenthic assemblages at the AS and BS farm stations, using groupaverage clustering of Bray-Curtis similarities. Dashed line shows the percentage of similarity beween the 3 formed groups at each farm. S: Summer; A: autumn; W: winter; Sp: spring 

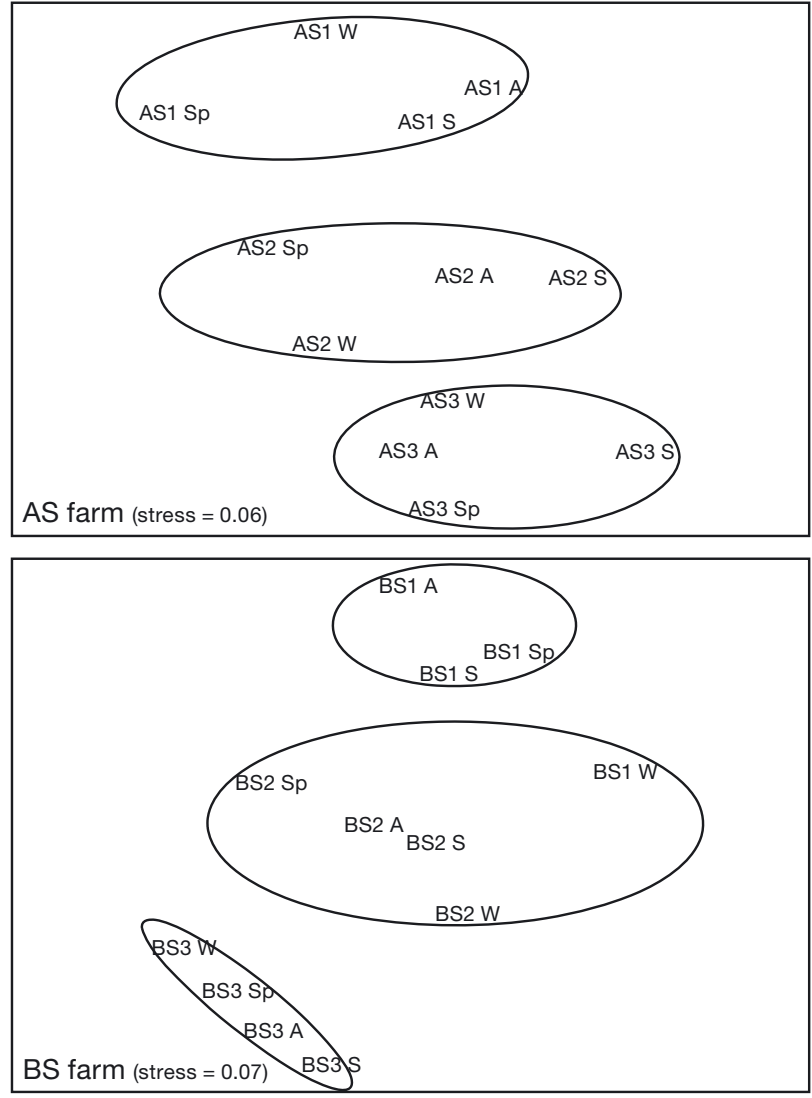

Fig. 4. Multidimensional scaling (MDS) ordination plots derived from species abundance data at the AS and BS farm stations. S: summer; A: autumn; W: winter; Sp: spring

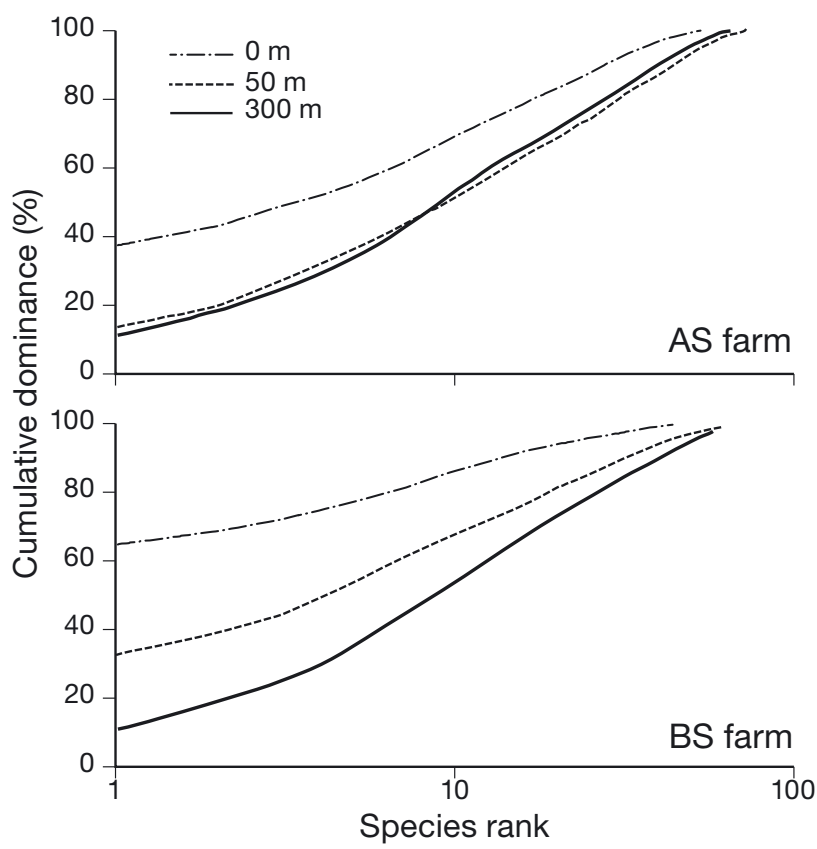

Fig. 5. K-dominance curves for the AS and BS farm stations at 0 (AS1, BS1), 50 (AS2, BS2) and 300 (AS3, BS3) m from the centre of respective fish farms during all sampling seasons the environment (Brooks \& Mahnken 2003a, Nash et al. 2005), although these changes are temporary and largely reversible. Organic carbon can be used as an indicator of the health of the benthic ecosystem, since it is correlated to benthic diversity (Kalantzi \& Karakassis 2006).

Previous studies in the Eastern Mediterranean have clearly demonstrated the effect of fish farming on the benthic environment (Karakassis et al. 2000, Belias et al. 2003, Klaoudatos et al. 2006, Yucel-Gier et al. 2007). In the present study, the benthic fauna showed marked changes in species numbers, abundance, biomass and diversity at the farm stations compared to the control stations. Nevertheless, the observed differences between community parameters were not statistically significant, except for species number, abundance and species richness at the BS farm. Furthermore, 1-way ANOVA indicated that the significant differences, detected in the benthic community parameters of the BS farm, were spatio-temporal for species number, temporal for abundance and spatial for species richness. According to Henderson \& Ross (1995), traditional biological endpoints, including abundance, species richness and Shannon's diversity index, are considered the best indicators of biological health.

The minimum number of species was encountered at the stations located under the centre of the cages. Nevertheless, this is not typical of a polluted zone as described by Pearson \& Rosenberg (1978). Furthermore, numerical abundance was higher at the farm stations (BS farm), whereas diversity index and evenness were higher at the control stations (AS and BS farms). According to Bellan-Santini et al. (1994), this is more obvious for oligotrophic systems like the Mediterranean Sea, where under normal conditions we observe low abundance and high diversity.

Species richness was lower at the farm stations compared to the control stations. It is generally expected that benthic assemblages respond to organic disturbance in terms of decreased species richness, due to a selection of a few opportunistic species (Ritz et al. 1989, Weston 1990) and reduced density and biomass (Frid \& Mercer 1989, Weston 1990), partially offset by the increased abundance of opportunistic species.

The additional food resource is likely to be exploited by opportunistic species. The polychaete Capitella capitata is an opportunistic macrofaunal species, which is commonly found in polluted marine sediments (Karakassis et al. 2000). A number of authors have reported the presence of this species under fish cages (Karakassis et al. 2000, Brooks 2001b, Klaoudatos et al. 2006, Mente et al. 2006). In some cases C. capitata reached almost $75 \%$ of the total abundance at farm sites (Karakassis et al. 2000). Brooks (2001b) reported that C. capitata was observed in $69 \%$ of all samples collected 
from 7 different salmon farms in British Columbia, Canada. Brown et al. (1987) and Weston (1990) reported a clear dominance of the macrofaunal community by C. capitata in the zone near cages. Reish (1972) also suggested that the presence of large numbers of C. capitata is indicative of polluted and semi-polluted conditions. In the present study, C. capitata did not exceed $65 \%$ of the total abundance (BS1) and was the most dominant species at the farm stations, but was almost absent at the control stations (presence $\leq 2 \%$ of the total abundance). On the other hand, the polychaete Nephthys hystricis was the most dominant species at the control stations $(11 \%$ of the total abundance at both stations) and was present at Stns AS2 and BS2 in low proportions $(\leq 2 \%)$, but was absent at Stns AS1 and BS1, which were located at the centre of the fish cages. This finding may imply that $N$. hystricis is an indicator of non-polluted marine sediments, which is in agreement with other authors (Karakassis et al. 2000).

SIMPER analysis indicates that the species mainly responsible for the dissimilarity between farm and control stations at both farms were principally the polychaetes Capitella capitata, Nephthys hystricis and Paraonis gracilis gracilis. Klaoudatos et al. (2006) reported that the principal species which were responsible for the dissimilarity between organic impacted and non-impacted sites in Hios Island (Greece, Eastern Mediterranean) were the polychaetes Nereis diversicolor, Hyalinoecia brementi, Scolelepis fuliginosa and C. capitata. The only species in common with our study was the polychaete C. capitata.

Cluster analysis, MDS ordination plots and K-dominance curves plotted for all sampling stations indicated spatial changes on macrobenthic assemblages with higher effects at the BS farm. Cluster analysis indicates that Stn BS1 clustered with Stn BS2 during winter. According to Hargrave et al. (1993) seasonal variability in macrofaunal variables is more pronounced at farm stations than at control stations, at a Canadian Atlantic salmon farm. Furthermore, K-dominance curves from the present study showed that disturbance of benthic community structure at the AS farm occurred up to $50 \mathrm{~m}$ from the centre of the cages, while at the BS farm it was found between 50 and $300 \mathrm{~m}$ from the centre of the cages. In another study of the Eastern Mediterranean, Klaoudatos et al. (2006) reported that the K-dominance curves displayed a non-significant elevated curve for samples from farm sites and control sites suggesting a minor impact on the benthic community at farm sites.

Studies on benthic impacts of cage aquaculture (Costa-Pierce 2002b) have shown that effects are localized. In Scottish West Coast waters, the main effect of benthic enrichment does not extend further than $50 \mathrm{~m}$ from the cages of the farm (Mente et al. 2006). Heinig
(2001), examining salmon aquaculture facilities in Maine, USA, reported that the effects of the net-pen operations on relative diversity of the benthos are generally confined to within 60 to $80 \mathrm{~m}$ of the structures. Two reports of monitoring open-ocean aquaculture sites in the USA provided no evidence of benthic impact from open-ocean operations (Bybee \& BaileyBrock 2003, Grizzle et al. 2003). Brooks (2001b) concluded that salmon farms in British Columbia, Canada, created significant changes in macrofaunal community that extended to between 205 and 225 m down-current during the peak of production. In the Eastern Mediterranean only a single study has investigated and presented the spatial effect (samples were taken at 5, 10, 25,50 and $100 \mathrm{~m}$ from the edge of the cages) of fish farming on benthic community structure (Karakassis et al. 2000). According to Karakassis et al. (2000), the macrofaunal community was affected up to $25 \mathrm{~m}$ from the edge of the cages. Most of the similar studies in other regions reported that the effects extend up to $50 \mathrm{~m}$ from the fish cages (Mente et al. 2006).

The conclusion from the present study is that despite the fact that the study area lies in a semi-enclosed gulf, the spatial extent of benthic assemblage disturbance due to fish farming is less than might be expected for such a location.

Acknowledgements. Thanks to Editor-in-Chief Dr M. Holmer, Contributing Editor Dr I. Karakassis, as well as to 3 anonymous reviewers for helpful comments on the manuscript.

\section{LITERATURE CITED}

Basaran AK, Aksu M, Egemen O (2010) Impacts of the fish farms on the water column nutrient concentrations and accumulation of heavy metals in the sediments in the eastern Aegean Sea (Turkey). Environ Monit Assess 162: $439-451$

Basurco B (2000) Offshore mariculture in Mediterranean countries. CIHEAM Options Méditerranéennes B 30:9-18

Basurco B, Larrazabal G (2000) Marine fish farming in Spain. CIHEAM Options Méditerranéennes B 30:45-56

Belias CV, Bikas VG, Dassenakis MJ, Scoullos MJ (2003) Environmental impacts of coastal aquaculture in eastern Mediterranean bays: the case of Astakos Gulf, Greece. Environ Sci Pollut Res 10:287-295

Bellan-Santini D, Lacaze JC, Poizat C (1994) Les Biocénoses Marines et Littorales des Cotes Françaises de Méditerranée: Synthèse, Menaces et Perspectives. Muséum National d'Histoire Naturelle, Paris

$>$ Bray JR, Curtis JT (1957) An ordination of the upland forest communities of southern Wisconsin. Ecol Monogr 27: 325-349

Brooks KM (2001b) An evaluation of the relationship between salmon farm biomass, organic inputs to sediments, physicochemical changes associated with those inputs and the infaunal response-with emphasis on total sediment sulfides, total volatile solids, and oxidation-reduction potential as surrogate endpoints for biological monitoring. 
Technical Advisory Group, Ministry of Environment, Nanaimo, BC

Brooks KM, Mahnken CVW (2003a) Interactions of Atlantic salmon in the Pacific northwest environment. II. Organic wastes. Fish Res 62:255-293

Brown JR, Gowen RJ, McLusky DM (1987) The effects of salmon farming on the benthos of a Scottish sea loch. J Exp Mar Biol Ecol 109:39-51

Buchanan JB (1971) Measurements of the physical and chemical environment. Sediments. In: Holme NA, Mc Intyre AD (eds) Methods for the study of marine benthos. IBP Handbook No 16, Oxford, p 30-52

Bybee DR, Bailey-Brock JH (2003) Effect of a Hawaiian open ocean fish culture system on the benthic community. In: Bridger CJ, Costa-Pierce BA (eds) Open ocean aquaculture: from research to commercial reality. The World Aquaculture Society, Baton Rouge, LA, p 119-128

Byers SC, Mills EL, Stewart L (1978) A comparisons of methods for determining organic carbon in marine sediments, with suggestion for a standard method. Hydrobiologia 58: $43-47$

Clarke KR, Gorley RN (2006) Primer v6: user manual/tutorial. PRIMER-E, Plymouth

Clarke KR, Warwick RM (1994) Change in marine communities: an approach to statistical analysis and interpretation. Natural Environment Research Council (NERC), Plymouth

Costa-Pierce BA (2002b) Ecology as the paradigm for the future of aquaculture. In: Costa-Pierce BA (ed) Ecological aquaculture. Blackwell Science, Oxford, p 340-372

> Delgado O, Ruiz J, Perez M, Romero J, Ballestreros E (1999) Effects of fish farming on seagrass (Posidonia oceanica) in a Mediterranean bay: seagrass decline after loading cessation. Oceanol Acta 22:109-117

Dempster T, Sanchez-Jerez P, Bayle-Sempere JT, GiménezCasalduero F, Valle C (2002) Attraction of wild fish to seacage fish farms in the south-western Mediterranean Sea: spatial and short-term temporal variability. Mar Ecol Prog Ser 242:237-252

Field JG, Clarke KR, Warwick RM (1982) A practical strategy for analysing multispecies distribution patterns. Mar Ecol Prog Ser 8:37-52

Findlay RH, Watling L, Mayer LM (1995) Environmental impact of salmon net-pen culture on marine benthic communities in Maine: a case study. Estuar Coasts 18: 145-179

Frid CLG, Mercer TS (1989) Environmental monitoring of caged fish farming in microtidal environments. Mar Pollut Bull 20:379-383

Gaudette HE, Flight WR, Toner L, Folger DW (1974) An inexpensive titration method for the determination of organic carbon in recent sediments. J Sediment Petrol 44:249-253

Grizzle RE, Ward LG, Langan R, Schnaittacher GM, Dijkstra JA, Adams JR (2003) Environmental monitoring at an open ocean aquaculture site in the Gulf of Maine: results for 1997-2000. In: Bridger CJ, Costa-Pierce BA (eds) Open ocean aquaculture: from research to commercial reality. The World Aquaculture Society, Baton Rouge, LA, p 105-117

Hall POJ, Holby O, Kollberg S, Samuelsson MO (1992) Chemical fluxes and mass balances in a marine fish cage farm. IV. Nitrogen. Mar Ecol Prog Ser 89:81-91

- Hargrave BT, Duplisea DE, Pfeiffer E, Wildish DJ (1993) Seasonal changes in benthic fluxes of dissolved oxygen and ammonium associated with marine cultured Atlantic salmon. Mar Ecol Prog Ser 96:249-257

Heinig CS (2001) The impacts of salmon aquaculture: the difficulties of establishing acceptability limits and standards.
In: Tlusty MF, Bengtson D, Halvorson HO, Oktay S, Pearce J, Rheault R (eds) Proc Mar Aquac Environ: A Meeting for Stakeholders in the Northeast, Boston, 11-13 Jan 2001. Cape Cod Press, Falmouth, MA

$>$ Henderson AR, Ross DJ (1995) Use of macrobenthic infaunal communities in the monitoring and control of the impact of marine cage fish farming. Aquac Res 26:659-678

Holby O, Hall POJ (1991) Chemical fluxes and mass balances in a marine fish cage farm. II. Phosphorus. Mar Ecol Prog Ser 70:263-272

> Hyland J, Balthis L, Karakassis I, Magni P and others (2005) Organic carbon content of sediments as an indicator of stress in the marine benthos. Mar Ecol Prog Ser 295:91-103

Kalantzi I, Karakassis I (2006) Benthic impacts of fish farming: meta-analysis of community and geochemical data. Mar Pollut Bull 52:484-493

Karakassis I, Tsapakis M, Hatziyanni E (1998) Seasonal variability in sediment profiles beneath fish farm cages in the Mediterranean. Mar Ecol Prog Ser 162:243-252

> Karakassis I, Hatziyanni E, Tsapakis M, Plaiti W (1999) Benthic recovery following cessation of fish farming: a series of successes and catastrophes. Mar Ecol Prog Ser 184: 205-218

Karakassis I, Tsapakis M, Hatziyanni E, Papadopoulou KN, Plaiti W (2000) Impact of cage farming of fish on the seabed in three Mediterranean coastal areas. ICES J Mar Sci 57:1462-1471

Karakassis I, Tsapakis M, Smith CJ, Rumohr H (2002) Fish farming impacts in the Mediterranean studied through sediment profiling imagery. Mar Ecol Prog Ser 227: 125-133

Katavic I, Antolic B (1999) On the impact of a sea bass (Dicentrarchus labrax L.) cage farm on water quality and macrobenthic communities. Acta Adriat 40:19-32

Klaoudatos SD, Klaoudatos DS, Smith J, Bogdanos K, Papageorgiou E (2006) Assessment of site specific benthic impact of floating cage farming in the eastern Hios island, Eastern Aegean Sea, Greece. J Exp Mar Biol Ecol 338: 96-111

La Rosa T, Mirto S, Mazzola A, Danovaro R (2001) Differential responses of benthic microbes and meiofauna to fish-farm disturbance in coastal sediments. Environ Pollut 112: 427-434

Machias A, Karakassis I, Labropoulou M, Somarakis S, Papadopoulou KN, Papaconstantinou C (2004) Changes in wild fish assemblages after the establishment of a fish farming zone in a oligotrophic marine ecosystem. Estuar Coast Shelf Sci 60:771-779

Machias A, Karakassis I, Giannoulaki M, Papadopoulou KN, Smith C, Somarakis S (2005) Response of demersal fish communities to the presence of fish farms. Mar Ecol Prog Ser 288:241-250

Maldonado M, Carmona MC, Echeverría Y, Riesgo A (2005) The environmental impact of Mediterranean cage fish farms at semi-exposed locations: Does it need a reassessment? Helgol Mar Res 59:121-135

Margalef DR (1958) Information theory in ecology. Gen Syst 3:36-71

Mazzola A, Mirto S, Danovaro R (2000) Fish-farming effects on benthic community structure in coastal sediments: analysis of meiofaunal resilience. ICES J Mar Sci 57:1454-1461

> Mente E, Pierce GJ, Santos MB, Neofitou C (2006) Effect of feed and feeding in the culture of salmonids on the marine aquatic environment: a synthesis for European aquaculture. Aquac Int 14:499-522

> Mirto S, La Rosa T, Gambi C, Danovaro R, Mazzola A (2002) Nematode community response to fish-farm impact in the 
western Mediterranean. Environ Pollut 116:203-214

Nash CE, Burbridge PR, Volkman JK (2005) Guidelines for ecological risk assessment of marine fish aquaculture. US Dept of Commerce, National Oceanic and Atmospheric Administration (NOAA) Tech Memo NMFS-NWFSC-71. Available at http://aquaculture.noaa.gov/pdf/afs_07_nash.pdf

Neofitou N, Klaoudatos S (2008) Effect of fish farming on the water column nutrient concentration in a semi-enclosed gulf of the Eastern Mediterranean. Aquac Res 39:482-490

Papageorgiou N, Kalantzi I, Karakassis I (2010) Effects of fish farming on the biological and geochemical properties of muddy and sandy sediments in the Mediterranean Sea. Mar Environ Res 69:326-336

Papoutsoglou S, Costello MJ, Stamou E, Tziha G (1996) Environmental conditions at sea-cages and ectoparasites on farmed European sea-bass, Dicentrarchus labrax (L.) and gilt-head sea-bream, Sparus aurata L., at two farms in Greece. Aquac Res 27:25-34

Pearson TH, Black KD (2001) The environmental impacts of marine fish cage culture. In: Black KD (ed) Environmental impacts of aquaculture. CRC Press, Boca Raton, FL, p 1-31

Pearson TH, Rosenberg R (1978) Macrobenthic succession in relation to organic enrichment and pollution of the marine environment. Oceanogr Mar Biol Annu Rev 16:229-311

Petihakis G, Triantafyllou G, Koliou A, Theodorou A (2002) Exploring the dynamics of a marine ecosystem (Pagasitikos Gulf, Western Aegean, Greece) through the analysis of temporal and spatial variability of nutrients. Proc 7th Int Conf Littoral 2002 - The Changing Coast, 22-26 Sep 2002, EUROCOAST Federation, Porto

Petihakis G, Triantafyllou G, Pollani A, Koliou A, Theodorou A (2005) Field data analysis and application of a complex water column biogeochemical model in different areas of a semi-enclosed basin: towards the development of an ecosystem management tool. Mar Environ Res 59:493-518

Pielou EC (1977) Mathematical ecology. John Wiley \& Sons, New York, NY

Editorial responsibility: Ioannis Karakassis, Heraklion, Greece
Pitta P, Karakassis I, Tsapakis M, Zivanovic S (1999) Natural vs. mariculture induced variability in nutrients and plankton in the eastern Mediterranean. Hydrobiologia 391:181-194

> Pohle G, Frost B, Findlay R (2001) Assessment of regional benthic impact of salmon mariculture within the Letang Inlet, Bay of Fundy. ICES J Mar Sci 58:417-426

Reish DJ (1972) The use of marine invertebrates as indicators of varying degrees of marine pollution. In: Ruino $M$ (ed) Marine pollution and sea life. Fishing News Books, London, p 404-411

> Ritz DA, Lewis M, Shen M (1989) Response to organic enrichment of infaunal macrobenthic communities under salmonid fish cages. Mar Biol 103:211-214

Ruiz JM, Pérez M, Romero J (2001) Effects of fish farm loadings on seagrass (Posidonia oceanica) distribution, growth and photosynthesis. Mar Pollut Bull 42:749-760

Shannon CE, Weaver N (1949) The mathematical theory of communication. University of Illinois Press, Urbana, IL

Tucker CS, Hargreaves JA (eds) (2008) Environmental best management practices for aquaculture. Blackwell Publishing, Ames, IA

- Wentworth CK (1922) A scale of grade and class terms for clastic sediments. J Geol 30:377-392

- Weston DP (1990) Quantitative examination of macrobenthic community changes along an organic enrichment gradient. Mar Ecol Prog Ser 61:233-244

> Wu RSS, Lam KS, MacKay DW, Lau TC, Yam V (1994) Impact of marine fish farming on water quality and bottom sediment: a case study in the sub-tropical environment. Mar Environ Res 38:115-145

Yucel-Gier G, Kucuksezgin F, Kocak F (2007) Effects of fish farming on nutrients and benthic community structure in the Eastern Aegean (Turkey). Aquac Res 38:256-267

Yucel-Gier G, Uslu O, Bizsel N (2008) Effects of marine fish farming on nutrient composition and plankton communities in the Eastern Aegean Sea (Turkey). Aquac Res 39: 181-194

Submitted: February 22, 2010; Accepted: August 24, 2010

Proofs received from author(s): September 24, 2010 